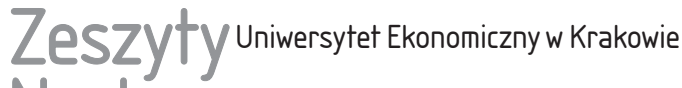 Naukowe
}

\author{
Danuta Golik \\ Dariusz Żmija \\ Katedra Polityki Ekonomicznej \\ i Programowania Rozwoju \\ Uniwersytet Ekonomiczny w Krakowie
}

\section{Perspektywy rozwoju przetwórstwa w sektorze cukrowniczym i mleczarskim w Polsce w świetle zmian WPR do 2020 roku}

\section{Streszczenie}

W artykule została poruszona problematyka rozwoju sektora mleczarskiego i cukrowniczego w Polsce na tle zmian wspólnej polityki rolnej do 2020 r. Podsumowano dotychczasowe reformy na obu rynkach, a także opisano przewidywane kierunki rozwoju badanych sektorów w nowym okresie programowania.

Słowa kluczowe: reforma rynku cukru, reforma rynku mleka, kwoty produkcyjne, wspólna polityka rolna.

\section{Wprowadzenie}

Przewidywane zmiany wspólnej polityki rolnej Unii Europejskiej po 2013 r. powodują określone konsekwencje dla wielu sektorów gospodarki żywnościowej, w tym zwłaszcza dla sektora cukrowniczego i mleczarskiego. Likwidacja kwotowania na rynku cukru w 2015 r., a także likwidacja mechanizmu kwotowania produkcji mleka w 2017 r. stwarzają nowe uwarunkowania działalności 
tych ważnych, z punktu widzenia pozycji Polski w unijnej produkcji, sektorów gospodarki.

Celem artykułu jest zatem diagnoza sytuacji w sektorze cukrowniczym i mleczarskim oraz próba przedstawienia możliwych kierunków zmian w tych sektorach w odniesieniu do organizacji rynku cukru i mleka w nowym okresie programowania.

\section{Założenia i cele unijnej reformy rynku cukru}

Funkcjonujący od 1968 r. w Unii Europejskiej system regulacji rynku cukru [Rozporządzenie... 1967], charakteryzujący się znacznym wsparciem producentów rolnych, bazujący na dopłatach do eksportu i utrzymywaniu cen przewyższających kilkakrotnie ceny na rynkach światowych, był przedmiotem krytyki ze strony Światowej Organizacji Handlu. Dotowany eksport cukru z Unii Europejskiej powodował, że światowe ceny rynku cukru utrzymywały się na niskim poziomie, co negatywnie wpływało na sytuację krajów rozwijających się. Celem unijnej reformy rynku cukru stała się z jednej strony konieczność dotrzymania zobowiązań wynikających z uzgodnień ze Światową Organizacją Handlu, a z drugiej strony potrzeba poprawy konkurencyjności europejskiego sektora cukrowniczego na rynku międzynarodowym. Realizując powyższe cele, Unia Europejska podjęła w 2006 r. działania w kierunku ograniczania produkcji cukru po niekonkurencyjnych cenach.

Główną zmianą w funkcjonowaniu rynku cukru była redukcja kwot produkcyjnych poprzez zmniejszenie o $23,5 \%$ limitu produkcji cukru do poziomu powyżej $13 \mathrm{mln}$ ton. Równocześnie utrzymano obowiązek eksportu lub zużycia na cele niespożywcze cukru pozakwotowego. W odniesieniu do cen zastąpiono cenę interwencyjną cukru ceną referencyjną, niższą o prawie $40 \%$ od ceny interwencyjnej. W rezultacie cena referencyjna uległa zmniejszeniu z 631,9 euro za tonę w sezonie 2006/2007 do poziomu 404,4 euro za tonę w sezonie 2009/2010 i w latach następnych. Jednocześnie obniżono o $40 \%$ minimalne ceny buraków cukrowych z poziomu 32,9 euro za tonę w sezonie 2006/2007 do poziomu 26,3 euro za tonę w sezonie 2009/2010 i w latach następnych. Aby zrekompensować obniżki cen, Komisja Europejska wprowadziła oddzielne płatności dla plantatorów buraków cukrowych, które miały docelowo w 64,2\% rekompensować utratę dochodów rolników, wynikającą z obniżenia minimalnych cen buraków cukrowych. Szczególną formą zachęty do rezygnacji z produkcji cukru stał się fundusz restrukturyzacyjny, stanowiący rodzaj zachęty do zaprzestania produkcji cukru przez producentów o najniższej konkurencyjności. Najwyższe rekompensaty przewidziane zostały dla tych przedsiębiorstw, które najwcześniej, czyli w roku gospo- 
darczym 2006/2007 oraz 2007/2008, zdecydują się na ograniczenie produkcji. Rekompensata wyniosła w badanym okresie 730 euro za tonę. W następnych latach, tj. w roku gospodarczym 2008/2009 oraz 2009/2010, była ona znacznie niższa i wynosiła odpowiednio 625 euro za tonę i 520 euro za tonę [Stankiewicz 2006, s. 1-8; Artyszak 2009, s. 5-8].

\section{Skutki reformy na rynku cukru dla polskiego sektora cukrowniczego}

W odróżnieniu od sytuacji istniejącej na unijnym rynku cukru, której efektem są istotne zmiany strukturalne w produkcji i przetwórstwie buraków cukrowych, przy znacznej, bo wynoszącej prawie $6 \mathrm{mln}$ ton redukcji produkcji cukru i konieczności jego importu na rynek unijny, przy konsumpcji szacowanej na ok. 17,5 mln ton, odnotować można w polskim sektorze cukrowniczym zarówno pozytywne, jak i negatywne skutki reformy (tabela 1).

Przed wejściem Polski do Unii Europejskiej Polska produkowała ok. $2 \mathrm{mln}$ ton cukru, w 2004 r. natomiast limit produkcji cukru wyniósł 1,6 mln ton, co zaspokajało potrzeby rynku wewnętrznego. Reforma rynku cukru w UE, polegająca na ograniczaniu bądź zaprzestaniu przez niektóre kraje UE produkcji cukru, spowodowała konieczność importu cukru przez Polskę w wysokości 200-250 tys. ton, przy kwocie produkcyjnej wynoszącej obecnie 1,4 mln ton. Zmniejszenie limitu produkcyjnego doprowadziło do głębokiej restrukturyzacji branży cukrowniczej na poziomie produkcji i przetwórstwa.

Zmniejszenie powierzchni uprawy buraków cukrowych o ponad $40 \%$, a także liczby plantatorów o połowę w porównaniu z okresem przed reformą doprowadziło do wzrostu koncentracji uprawy buraków w regionach o najlepszych glebach i dużych gospodarstwach. Pozytywnym tego aspektem jest wzrost średniej plantacji do prawie 5,5 ha, a także wzrost średnich plonów do 50 t/ha. Duży wzrost koncentracji nastąpił w przemyśle cukrowniczym, gdyż liczba czynnych cukrowni uległa zmniejszeniu z 76 do 18 obecnie działających. Likwidacji cukrowni towarzyszył spadek zatrudnienia o $60 \%$ do liczby 4 tys. osób, przy wzroście technicznej wydajności pracy w 2010 r. o $70 \%$ [Szajner 2011a, s. 8-9; Szajner 2009, s. 182-191].

W warunkach reformy nastąpiła dalsza koncentracja struktury własnościowej sektora cukrowniczego. W Polsce do 2009 r. cukrownie funkcjonowały w strukturach pięciu koncernów cukrowniczych, w tym czterech z większościowym udziałem kapitału zagranicznego. Od połowy 2009 r. działają w Polsce tylko cztery koncerny cukrownicze (British Sugar Polska wycofał się z rynku), a największy, tj. Krajowa Spółka Cukrowa, ma ok. 40\% udziału w rynku. 
Tabela 1. Efekty unijnej reformy rynku cukru z 2006 r.

\begin{tabular}{|c|c|}
\hline Skutki reformy dla krajów UE & Skutki reformy dla Polski \\
\hline $\begin{array}{l}\text { - zmniejszenie produkcji cukru o ok. } 6 \text { mln } \\
\text { ton, } \\
\text { - całkowita rezygnacja z produkcji cukru } \\
\text { pięciu państw członkowskich UE (Irlandii, } \\
\text { Portugalii, Bułgarii, Łotwy i Słowenii), } \\
\text { - koncentracja produkcji (prawie } 75 \% \text { kwoty } \\
\text { produkcyjnej) w sześciu państwach UE } \\
\text { (Francja, Niemcy, Polska, Wielka Brytania, } \\
\text { Holandia i Belgia), } \\
\text { - mniejszy eksport cukru z UE, a większy } \\
\text { import do UE, } \\
\text { - mniejszy areał uprawy buraka cukrowego } \\
\text { w UE o ok. } 800 \text { tys. ha, } \\
\text { - mniejsza liczba plantatorów w UE o ok. } 140 \\
\text { tys., } \\
\text { - redukcja miejsc pracy w branży cukrowni- } \\
\text { czej o ok. } 17 \text { tys. osób. }\end{array}$ & $\begin{array}{l}\text { - ograniczenie kwoty produkcji cukru o } 13 \% \\
\text { w stosunku do krajowego spożycia i o } 16 \% \\
\text { w stosunku do limitu uzyskanego w negocja- } \\
\text { cjach akcesyjnych, } \\
\text { - zmniejszenie liczby czynnych cukrowni z } 76 \\
\text { przed wejściem reformy do } 18 \text { obecnie, } \\
\text { - zmniejszenie powierzchni uprawy buraków } \\
\text { cukrowych z } 286 \text { tys. ha przed wejściem } \\
\text { reformy do poziomu } 195,5 \text { tys. ha w sezonie } \\
\text { 2011/2012, } \\
\text { - zmniejszenie liczby plantatorów na rynku } \\
\text { cukru z 70,7 tys. przed wejściem reformy do } \\
\text { wielkości } 35,8 \text { tys. w sezonie } 2011 / 2012, \\
\text { - zwiększenie przeciętnej powierzchni uprawy } \\
\text { buraków cukrowych w przeliczeniu na jed- } \\
\text { nego plantatora z } 4,05 \text { ha przed reformą do } \\
\text { poziomu 5,5 ha w sezonie } 2011 / 2012, \\
\text { - przyspieszenie procesu restrukturyzacji } \\
\text { przemysłu cukrowniczego, } \\
\text { - wzrost koncentracji uprawy buraków cukro- } \\
\text { wych w regionach o najlepszych glebach } \\
\text { i dużych gospodarstwach, } \\
\text { - zwiększenie średniej plantacji buraków } \\
\text { cukrowych z poziomu } 3,8 \text { ha przed reformą } \\
\text { do poziomu } 5,45 \text { ha w sezonie } 2011 / 2012, \\
\text { - wzrost średnich plonów z poziomu } 41,6 \text { t/ha } \\
\text { w okresie przed reformą do poziomu } 50 \text { t/ha } \\
\text { w } 2010 \text { r., } \\
\text { - koniecznośc importu cukru na rynek } \\
\text { wewnętrzny w wysokości } 200-250 \text { tys. ton } \\
\text { rocznie, } \\
\text { - redukcja zatrudnienia w branży cukrowni- } \\
\text { czej z poziomu } 10 \text { tys. osób przed reformą do } \\
\text { liczby } 4 \text { tys. osób w } 2010 \text { r. }\end{array}$ \\
\hline
\end{tabular}

Źródło: opracowanie własne na podstawie [Rynek cukru... 2011, s. 3; Mucha 2010, s. 65] oraz danych Krajowego Związku Plantatorów Buraka Cukrowego.

Jak już wspomniano, jednym z głównych celów reformy rynku cukru była poprawa konkurencyjności cenowej sektora. Zmniejszenie produkcji cukru oraz wzrost światowych cen surowców spowodowały, że ceny cukru w UE zamiast spadać, zaczęły odnotowywać tendencję wzrostową. W Polsce wzrost cen zbytu i cen detalicznych cukru nastąpił od połowy 2010 r. Głównymi czynnikami wzrostu tych cen były spadek produkcji cukru i stabilny popyt na rynku wewnętrznym, a także wysokie ceny cukru na giełdach światowych (600-800 dol. za tonę). Szcze- 
gólnie duży wzrost cen wystąpił w pierwszym kwartale 2011 r., kiedy ceny zbytu wynosiły w Polsce ok. 3 zł $/ \mathrm{kg}$, a ceny detaliczne przekraczały 5 zł $/ \mathrm{kg}$.

Wysokie ceny zbytu w Polsce i w eksporcie przyczyniły się do poprawy sytuacji finansowej sektora cukrowniczego. Dobra koniunktura na rynku zrekompensowała częściowo niekorzystne skutki reformy, w tym różnice między wartością wpłaconych składek przez koncerny cukrownicze, w łącznej kwocie wynoszącej prawie $650 \mathrm{mln}$ euro, a wartością wypłaconej pomocy restrukturyzacyjnej, wynoszącej ponad $280 \mathrm{mln}$ euro, w tym 180,4 mln euro dla przemysłu cukrowniczego [Szajner 2011a].

Zaznaczyć należy, że zmienia się struktura spożycia cukru w Polsce. Systematycznie maleje bezpośrednie spożycie cukru w gospodarstwach domowych, a wzrasta jego zużycie w przemyśle spożywczym i innych działach gospodarki. Przykładowo w 2010 r. spożycie cukru w gospodarstwach domowych wyniosło $15,6 \mathrm{~kg}$ na osobę, podczas gdy w 2004 r. wynosiło 19,4 kg na osobę. Powodem spadku spożycia są przede wszystkim zmiany w modelu konsumpcji. Równocześnie wzrasta konsumpcja i eksport artykułów spożywczych zawierających cukier, co prowadzi do wzrostu zużycia cukru w przemyśle spożywczym. Cukier jest wykorzystywany w większości działów wtórnego przetwórstwa żywności, ale największe znaczenie posiadają tutaj napoje bezalkoholowe i soki, wyroby przemysłu cukierniczego, lody i jogurty oraz przetwory owocowe.

\section{Sektor mleczarski w Polsce w warunkach kwotowania produkcji}

Na rynku mleka, podobnie jak na rynku cukru, podstawę systemu regulacji produkcji stanowią kwoty mleczne. Polska wynegocjowała w traktacie akcesyjnym kwotę mleczną wynoszącą 9,38 mln ton, która zgodnie z Rozporządzeniem Rady Unii z 17 marca 2008 r. wzrośnie do poziomu ponad 10 mln ton w roku gospodarczym 2014/2015, jednakże będzie ona mniejsza od produkcji wynoszącej $12 \mathrm{mln}$ ton (tabela 2).

Problemem polskiego mleczarstwa pozostaje wzrastający po integracji Polski z UE, ale wciąż niższy niż w UE-15, wskaźnik towarowości produkcji wynoszący w 2011 r. 80\%, w odróżnieniu od średniej UE-15, w której jest on na poziomie 95\%. Jednocześnie zauważyć można niepełne wykorzystanie kwoty mlecznej w Polsce, wynoszące średnio w latach 2004-2011 97\%, a w roku gospodarczym 2010/2011 zaledwie 95\% [Szajner 2011b, s. 2-3]. Utrzymująca się od połowy 2008 r. do połowy 2010 r. spadkowa tendencja cen skupu mleka spowodowała redukcję pogłowia krów mlecznych z poziomu 2697 w 2008 r. do poziomu 2529 w 2010 r. (tabela 2). Jeszcze szybciej ubywało dostawców mleka oraz gospodarstw utrzymujących krowy. 
Tabela 2. Podstawowe dane o sektorze mleczarskim w Polsce w latach 2008-2012

\begin{tabular}{|l|c|c|c|c|c|}
\hline \multicolumn{1}{|c|}{ Wyszczególnienie } & 2008 & 2009 & 2010 & 2011 & 2012 \\
\hline Produkcja mleka (w mln litrów) & 12064 & 12084 & 11921 & 12060 & 12600 \\
\hline $\begin{array}{l}\text { Pogłowie krów mlecznych (w tys. } \\
\text { sztuk - stan w grudniu) }\end{array}$ & 2697 & 2570 & 2529 & 2510 & 2346 \\
\hline $\begin{array}{l}\text { Zużycie mleka w gospodarstwach } \\
\text { rolnych, z tego: }\end{array}$ & 2600 & 2450 & 2350 & 2300 & 2215 \\
- na pasze & 550 & 500 & 500 & 500 & 515 \\
- na spożycie & 2050 & 1950 & 1850 & 1800 & 1700 \\
\hline $\begin{array}{l}\text { Sprzedaż razem, } \\
\text { z tego: }\end{array}$ & 9464 & 9634 & 9571 & 9760 & 9781 \\
- do przemysłu mleczarskiego & 8567 & 8846 & 8725 & 8958 & 9000 \\
- do innych przetwórców & 120 & 32 & 36 & 37 &. \\
- inna sprzedaż (bezpośrednia) & 777 & 756 & 810 & 766 &. \\
\hline Towarowość produkcji (w \%) & 78,4 & 79,7 & 80,3 & 80,9 & 82 \\
\hline Udział skupu w produkcji (w \%) & 71 & 73,2 & 73,2 & 74,3 & 77,6 \\
\hline $\begin{array}{l}\text { Liczba dostawców mleka (w tys.), } \\
\text { w tym: } \\
\text { dostawcy hurtowi }\end{array}$ & 222 & 200 & 186 & 183 & 156,4 \\
\hline Wydajność mleczna krów (w 1/szt.) & 4473 & 4702 & 4714 & 4805 & 5249 \\
\hline
\end{tabular}

Źródło: obliczenia własne na podstawie [Rynek mleka... 2011, s. 3; Informacja ARR ... 2012, s. 7; Śmigielska 2013, s. 3-7].

Spadek opłacalności produkcji w wymienionym okresie spowodował proces koncentracji produkcji. Zmalała liczba gospodarstw utrzymujących do 9 krów oraz gospodarstw utrzymujących 10-29 krów, wzrosła natomiast liczba gospodarstw utrzymujących 30-99 krów oraz powyżej 200 krów [Seremak-Bulge 2011, s. 14-15; Szajner 2011b].

Koncentracji produkcji towarzyszy wzrost jej towarowości. Dla porównania przed akcesją Polski do Unii Europejskiej do przemysłu mleczarskiego trafiało 60\% wyprodukowanego mleka, natomiast w latach 2009-2010 na sprzedaż przeznaczano $80 \%$ wyprodukowanego mleka, z czego $73 \%$ skupił przemysł mleczarski. Koncentracja produkcji miała wpływ również na wzrost wydajności krów mlecznych, która zwiększyła się z poziomu 4473 l/szt. w 2008 r. do poziomu 4714 1/szt. w 2010 r. W 2012 r. wydajność krów wyniosła ponad 5000 l/szt. Zaznaczyć przy tym należy, że jest ona znacznie niższa niż średnia wydajność w UE-27, która wyniosła w 2010 r. blisko 6500 1/szt [Olkowska 2012, s. 9].

Proces koncentracji w przetwórstwie mleka przebiega wolniej niż w procesie produkcji. W 2010 r. liczba mleczarni w porównaniu do 2004 r. zmniejszyła się o 60 do wysokości 205. Jednakże przerób mleka w Polsce w porównaniu np. z Niemcami, przy zbliżonej liczbie mleczarni jest ponad trzy razy niższy. Mimo że 
pięć największych mleczarni w Polsce ma ponad 40-procentowy udział w rynku, to wartość ich sprzedaży kształtuje się w przedziale 360-500 mln rocznie na przedsiębiorstwo. Największe przedsiębiorstwa zajmujące się przetwórstwem mleka w UE-15 są 10-20 razy większe. Niewielkie wykorzystanie kwot mlecznych powoduje z kolei, że zdolności przetwórcze przemysłu mleczarskiego w Polsce są wykorzystywane na poziomie $75-80 \%$, co w sytuacji nadmiaru mocy produkcyjnych powoduje wysokie koszty i utrudnia czerpanie korzyści z efektów skali.

Wzrost od połowy 2009 r. światowego popytu na produkty mleczarskie oraz obrotów handlowych, które rosły szybciej niż produkcja mleka, spowodowały korzystną koniunkturę, skutkującą zwiększeniem cen produktów mleczarskich. W rezultacie tego średnia cena skupu w UE-27 w marcu 2011 r. wyniosła 33,3 euro/kg i była wyższa o 18\% niż w tym samym miesiącu $2010 \mathrm{r}$. Tendencje wzrostowe cen skupu mleka wystąpiły również w Polsce w badanym okresie. Przykładowo w kwietniu 2011 r. za mleko dostawcy otrzymali 120,42 zł/100 1, czyli o ponad 19\% więcej niż w kwietniu 2010 r. [Zmiany na rynku mleka... 2011, s. 13-14].

Problemem polskiego sektora mleczarskiego jest mały popyt wewnętrzny i duże uzależnienie od koniunktury na rynkach światowych. Spożycie mleka w Polsce jest nieduże i wynosi ok. 270 1/osobę, przy średniej unijnej dla krajów UE-15 wynoszącej 320 1/osobę. Równocześnie dodać należy, że w krajach skandynawskich spożycie to wzrasta do 470 litrów na osobę. W warunkach szybszego wzrostu produkcji mleka niż jego spożycia występuje nadwyżka podaży nad popytem. Wskaźnik samowystarczalności na rynku mleka, mierzony udziałem spożycia i zużycia paszowego w produkcji, wyniósł przykładowo w 2010 r. 108\%.

Nadwyżka podaży nad popytem powoduje, że Polska jest od lat eksporterem mleka i jego przetworów. Co czwarty skupiony kilogram mleka przeznaczany jest na eksport. Wartość eksportu wyniosła w 2010 r. 1,2 mld euro i była wyższa w porównaniu z 2009 r. o ponad 27\%. Prawie 80\% eksportu produktów mleczarskich trafia na rynek Unii Europejskiej. Wprawdzie eksport kilkakrotnie przewyższa import, jednak różnice te maleją. I tak w latach 2009-2010 eksport przewyższał 2,5-3 razy import, podczas gdy w latach 2004-2008 był 4-6 razy wyższy [Rynek mleka... 2011, s. 3].

\section{Rynek cukru i mleka a przewidywane zmiany WPR w latach 2014-2020}

W maju 2008 r. Komisja Europejska przedstawiła propozycje rezygnacji z systemu kwotowania produkcji mleka w Unii Europejskiej. Przewidywały one dwa możliwe scenariusze likwidacji kwoty mlecznej wraz z oceną ich wpływu na 
rynek mleka. Nazwane one zostały „miękkim lądowaniem” i „twardym lądowaniem" [Bouamra-Mechemache, Jongeneel i Requillart 2008]. Ocena wpływu tych dwóch wariantów na rynek mleka w państwach UE została dokonana na podstawie dokumentu Economic Analysis of the Effects of the Expiry of the EU Milk Quota System, przygotowanego na zlecenie Komisji Europejskiej [Requillart 2008]. W celu określenia perspektyw rynku mleka i przetworów mlecznych po zniesieniu systemów kwotowania powołano Grupę Ekspertów Wysokiego Szczebla ds. Mleka. Efektem działalności tej grupy są propozycje legislacyjne Komisji Europejskiej dotyczące zmian na tym rynku [Świtłyk i Wilczyński 2012, s. 86].

W październiku 2011 r. Komisja Europejska przedstawiła projekty rozporządzeń określających przyszły kształt regulacji rynku mleka i jego przetworów. Przedstawione propozycje likwidują dopłaty do mleka odtłuszczonego oraz odtłuszczonego mleka w proszku przeznaczonego do produkcji pasz oraz kazeiny i kazeinianów. Propozycje te podtrzymują decyzje o zaprzestaniu stosowania systemu kwotowania produkcji mleka w 2015 r., które zawarte zostały w rozporządzeniu Rady (WE) nr 72/2009z 19 stycznia 2009 r. [Rozporządzenie... 2009], jednak proponują dodatkowo przepisy tzw. pakietu mlecznego, który ma obowiązywać do 30 czerwca 2020 r. i łagodzić skutki likwidacji tego systemu. Pakiet mleczny umożliwia m.in. stosowanie obowiązkowych umów kontraktacyjnych oraz negocjowanie cen przez organizacje producentów i ich zrzeszenia.

Przedstawione rozwiązania są kontynuacją procesu liberalizacji rynków rolnych i zasygnalizowane zostały podczas przeglądu wspólnej polityki rolnej (tzw. Health Check) z 2008 r. Przygotowania do wdrożenia reformy w sektorze mleka trwają już od jakiegoś czasu. Dokonuje się pewnych dostosowań, które sprzyjają łagodnemu wycofaniu tego mechanizmu, pozwalając jednocześnie na uniknięcie nadmiernej regulacji po wycofaniu kwot. Stopniowo zwiększono krajowe kwoty mleczne o 2\% w roku kwotowym 2008/2009 oraz o 1\% na każdy rok kwotowy od 2009/2010 do 2013/2014. Wprowadzono także wyższe opłaty z tytułu nadprodukcji w dostawach (lata 2009/2010 i 2010/2011), a także dokonano zmiany w poziomie tłuszczu w dostarczanym mleku. W 2010 r. Komisja Europejska przedstawiła sprawozdanie z rozwoju sytuacji na rynku mleka, z którego wynika, że w coraz większej liczbie państw Unii produkcja mleka była mniejsza niż kwoty. Pomimo zwiększenia kwot o 2\% w roku kwotowym 2008/2009, któremu towarzyszyła dodatkowo korzystna koniunktura w zakresie cen mleka płaconych producentom, produkcja w 2008 r. wzrosła jedynie nieznacznie. O ile w roku kwotowym 2008/2009 opłatę za przekroczenie kwoty krajowej poniosło sześć państw UE, o tyle w roku kwotowym 2009/2010 były to już jedynie trzy państwa. Powyższym tendencjom towarzyszył również spadek cen kwot mlecznych w miarę skracania się okresu obowiązywania systemu kwotowego - w większości państw członkowskich były bardzo niskie lub bliskie zera. Powyższe 
zjawiska wskazywały na to, że odbywa się proces stopniowego dostosowywania do systemu bezkwotowego.

Kierunki zmian na rynku mleka po 2015 r. określone zostały w projekcie tzw. pakietu mlecznego, który reguluje stosunki umowne w sektorze mleka i przetworów mlecznych. W propozycji tej założono wprowadzenie kontraktacji na dostawę mleka, przy pozostawieniu państwom członkowskim swobody wyboru odnośnie do obowiązku zawierania pisemnych umów na dostawy mleka pomiędzy jego producentami a podmiotami zajmującymi się skupem lub przetwórstwem. Dodatkowym elementem, który zakłada pakiet mleczny, jest obowiązek składania sprawozdań miesięcznych przez przetwórców mleka o ilości dostarczonego do nich mleka surowego. Sprawozdanie takie składane byłoby do właściwego organu krajowego. Projekt przewiduje także możliwość negocjowania umów na dostawy mleka przez zatwierdzone organizacje producentów mleka i przetworów mlecznych w imieniu należących do nich rolników. Dokument propaguje także zakładanie organizacji międzybranżowych w sektorze mleka i przetworów mlecznych składających się z przedstawicieli producentów lub przetwórców mleka i przetworów mlecznych lub podmiotów zajmujących się handlem nimi [Biuletyn informacyjny... 2011, s. 29-31].

W okresie programowania 2014-2020 przewiduje się także wprowadzenie istotnych zmian w organizacji rynku cukru. W 2017 r. system kwotowania produkcji cukru ma zostać zniesiony, gdyż zdaniem Komisji Europejskiej utrudnia on sektorowi odpowiednio szybką reakcję na zmiany na rynku. Rozwiązanie to ma również ograniczyć obciążenia administracyjne i znaczną biurokrację w państwach członkowskich. Zniesienie kwot powinno spowodować zwiększenie produkcji cukru, co skutkować będzie obniżeniem ceny zarówno cukru, jak i buraków cukrowych. Możliwe jest jednak także, że ceny unijne charakteryzować się będą większą zmiennością w zależności od cen na rynkach światowych. Zniesienie kwotowania powinno przyczynić się do zwiększenia konkurencyjności sektora.

Inne zmiany na rynku cukru obejmować będą m.in. zniesienie ceny minimalnej na buraki cukrowe oraz wprowadzenie obligatoryjnych umów kontraktacyjnych na buraki cukrowe w celu zapewnienia równowagi praw i obowiązków między przedsiębiorstwami cukrowniczymi a plantatorami buraków cukrowych. Biały cukier zgodnie z proponowanymi zmianami zostanie objęty systemem dopłat do prywatnego przechowywania, a ceny referencyjne dla cukru białego i surowego mają pozostać na tym samym poziomie.

Wiele państw członkowskich (w tym Polska) jest przeciwnych zniesieniu systemu kwot. Jako główne zagrożenie wymienia brak stabilności rynku spowodowany znaczną zmiennością cenową. Propozycja ta jest również przedmiotem krytyki państw trzecich, zwłaszcza krajów rejonu Afryki, Karaibów i Pacyfiku oraz państw najsłabiej rozwiniętych, które obawiają się, że nielimitowana 
produkcja cukru z Unii Europejskiej zagrozi konkurencyjności ich produkcji. Również Stowarzyszenie Europejskich Producentów Cukru (CEFS) chce utrzymać kwoty cukrowe do 2020 r. Umożliwiłoby to kontynuację procesów zwiększania konkurencyjności i efektywności, które zapoczątkowała reforma z 2006 r. Utrzymanie kwot sprzyja stabilności rynku i przeciwdziała niekorzystnym wahaniom na rynku światowym. Jako główny argument za utrzymaniem kwot cukrowych Europejskie Stowarzyszenie Handlowców Cukrem (ASSUC) wymienia gwarancję stabilnych warunków dla wdrażania preferencyjnych umów handlowych. Zniesienie kwot może spowodować zdaniem ASSUC koncentrację produkcji cukru u niewielkiej liczby producentów. Podobne stanowisko reprezentują Międzynarodowa Konfederacja Europejskich Producentów Buraków (CIBE) oraz komitet Copa-Cogeca. Jako wady tego rozwiązania wymieniają niebezpieczeństwo destabilizacji rynku oraz prawdopodobne pogorszenie sytuacji ekonomicznej sektora. Zmiany na rynku cukru wspiera natomiast Stowarzyszenie Europejskich Użytkowników Cukru (CIUS), które reprezentuje producentów spożywczych wykorzystujących cukier. Zdaniem CIUS zniesienie kwot cukrowych oraz stopniowa redukcja barier przywozowych są rozwiązaniami sprzyjającymi budowie prawidłowo funkcjonującego, zdrowego i stabilnego rynku cukru w Unii Europejskiej [Biuletyn informacyjny... 2012, s. 25-27].

\section{Perspektywy rozwoju rynku mleka i cukru w Polsce}

Opracowania sporządzone w 2009 r. przez Instytut Perspektywicznych Studiów Technologicznych w Sewilli, wchodzący w skład Wspólnego Centrum Badawczego Komisji Europejskiej, dotyczące prognoz dla rynku mleka i przetworów mlecznych, wskazują, że zniesienie systemu kwotowania produkcji w $2015 \mathrm{r}$. spowoduje spadek cen skupu mleka w Polsce w 2020 r. średnio o 10\% w porównaniu z sytuacją, gdyby limity produkcyjne zostały utrzymane. Powyższa sytuacja będzie konsekwencją wzrostu produkcji mleka. Wszystkie trzy opracowania przeprowadzone przez Instytut Perspektywicznych Studiów Technologicznych wskazują, że ceny skupu mleka w krajach UE-15 i w Polsce nie ulegną wyrównaniu. Różnica ta waha się w przedziale od 9 euro za $100 \mathrm{~kg}$ mleka do 3,7 euro za $100 \mathrm{~kg}$ mleka w zależności od opracowania. Taka sytuacja niekorzystnie wpłynie na rentowność polskich gospodarstw, w których następuje wyrównanie kosztów produkcji mleka w stosunku do państw UE-15. Przyszła sytuacja ekonomiczna gospodarstw mlecznych nie będzie zatem korzystna. Szczególnie gospodarstwa o niewielkim stadzie staną przed koniecznością dokonania wyboru odnośnie do zaprzestania dalszej działalności lub też jej powiększenia, co jednak wiązać się musi z dużymi wydatkami inwestycyjnymi. Może zatem dojść do wyeliminowania najmniejszych 
gospodarstw z rynku [Baer-Nawrocka i Kiryluk-Dryjska 2010]. Z badań przeprowadzonych przez M. Świtłyk i A. Wilczyńskiego [2012] wynika, że spadek dochodowości przewidywany jest także w gospodarstwach o większym stadzie.

Podobne wyniki przynoszą symulacje przeprowadzone przez Instytut Perspektywicznych Studiów Technologicznych w Sewilli, które wskazują, że dochód rolniczy polskich gospodarstw po likwidacji kwot mlecznych zmniejszy się w porównaniu z sytuacją, gdyby kwoty te były utrzymane. Spadek ten średnio dla wszystkich gospodarstw prognozowany jest w przedziale 2,4-6,6\% w zależności od modelu, który posłużył symulacjom. Komisja Europejska przewiduje, że liczba krów w Unii Europejskiej będzie się systematycznie zmniejszać i w 2020 r. będzie mniejsza średnio o 7\% w stosunku do 2010 r. Równocześnie prognozowane jest zwiększenie produkcji średnio o 4\%, co wynikać będzie ze zwiększenia wydajności mlecznej od krowy do $6930 \mathrm{~kg} / \mathrm{szt}$. w 2020 r. Szacuje się, że w Polsce w tym samym okresie liczba krów mlecznych zmniejszy się do ok. 2 mln sztuk, zaś średnia wydajność mleczna wzrośnie o 16\%. Zmianom tym towarzyszyć będą przekształcenia struktury polskich gospodarstw mlecznych - szacuje się, że w 2020 r. większość pogłowia krów mlecznych będzie znajdować się w posiadaniu gospodarstw o stadzie od 25 do 50 krów, a nie jak obecnie - od 5 do 29 krów. Jest jednak mało prawdopodobne, żeby zniesienie kwot mlecznych wpłynęło znacząco na zwiększenie liczby gospodarstw posiadających powyżej 100 krów, z uwagi na barierę inwestycyjną [Świtłyk i Wilczyński 2012, s. 94-96].

W sektorze cukrowniczym nadal postępuje proces koncentracji uprawy buraków cukrowych. Liczba plantatorów w sezonie 2011/2012 zmniejszyła się do ok. 36 tys., a powierzchnia średniej plantacji wzrosła do 5,29 ha. W porównaniu z państwami UE-15 sektor nadal jednak charakteryzuje się rozdrobnioną strukturą. Trudno jest ocenić ostateczne skutki zniesienia kwot cukrowych. Z pewnością oznaczałoby to większe uzależnienie rynku unijnego od rynku światowego. Ponadto zniesienie kwot produkcyjnych może spowodować dalszą koncentrację upraw buraków cukrowych i tym samym produkcji cukru w UE. Zniesienie kwot cukrowych w UE może spowodować zamknięcie kolejnych cukrowni oraz zaprzestanie uprawy buraków cukrowych w wielu krajach członkowskich. Beneficjentami zmian w sektorze cukru oprócz podmiotów gospodarczych używających cukru w celach przetwórczych byliby prawdopodobnie zwykli konsumenci oraz przedsiębiorcy zajmujący się handlem detalicznym cukrem z uwagi na oczekiwany spadek cen cukru w Unii.

\section{Wnioski}

Zasadniczym celem reformy sektora cukrowniczego wprowadzonej w $2006 \mathrm{r}$. była poprawa konkurencyjności tego sektora oraz stabilizacja rynku. Pod 
względem konkurencyjności cel ten nie został osiągnięty, ponieważ w wielu przypadkach ograniczenie produkcji cukru wystąpiło w regionach, które nie należały do najmniej konkurencyjnych. Jeżeli chodzi o stabilizację rynku, wskazać należy, że pomimo uzyskania większej stabilizacji cen cukru niż przed reformą problemem nadal pozostaje niższa podaż cukru w stosunku do zapotrzebowania rynku Unii Europejskiej. Unia Europejska z eksportera netto stała się importerem netto cukru. Obecnie 20\% zapotrzebowania pokrywane jest importem z krajów trzecich. Sytuacja taka powoduje uzależnienie zaopatrzenia w cukier w Unii od produkcji pochodzącej z krajów trzecich. Funkcjonujący obecnie system kwot cukrowych nakłada liczne obostrzenia i ograniczenia powodujące sztywność zdolności produkcyjnych i małą możliwość zwiększenia wydajności producentów i plantatorów. Powoduje to niekorzystny wpływ na konkurencyjność plantatorów buraków i producentów, hamując rozwój rynku. Zauważyć również należy, że w UE zwiększa się zapotrzebowanie na dostawy cukru w związku z jego nowym zastosowaniami, np. produkcja bioetanolu. Powoduje to rosnące uzależnienie UE od importu cukru, który jest towarem strategicznym dla przemysłu rolno-spożywczego i chemicznego.

W Polsce reforma rynku cukru z 2006 r. przyczyniła się m.in. do zmniejszenia powierzchni uprawy buraków cukrowych oraz liczby plantatorów o połowę w porównaniu z okresem przed reformą. Doprowadziło to do wzrostu koncentracji uprawy buraków w regionach o najlepszych glebach i dużych gospodarstwach. W Polsce nastąpiła także dalsza koncentracja struktury własnościowej sektora cukrowniczego. Zmiany zaproponowane w organizacji rynku cukru w nowym okresie programowania przewidują m.in. zniesienie systemu kwotowania produkcji cukru w Unii Europejskiej. Dużo państw członkowskich jest przeciwnych zniesieniu systemów kwot, wymieniając jako główne zagrożenie brak stabilności rynku spowodowany znaczną zmiennością cenową. Ponadto zniesienie kwot produkcyjnych może sprzyjać dalszej koncentracji upraw buraków cukrowych oraz produkcji cukru, a także bardziej uzależnić rynek unijny od rynku światowego.

Likwidacja systemu kwotowania produkcji mleka będzie skutkować wieloma zmianami na tym rynku, co wpłynie na funkcjonowanie gospodarstw rolnych oraz producentów mleka. Prognozuje się, że likwidacja systemu kwotowania produkcji mleka doprowadzi w konsekwencji do zwiększenia produkcji mleka na rynku UE, co pociągnie za sobą spadek cen skupu mleka. Powyższe wskazuje na konieczność dostosowania się producentów mleka do nowej sytuacji w celu przeciwdziałania negatywnym skutkom likwidacji systemu kwotowania produkcji, m.in. spadek rentowności produkcji. Niezbędna wydaje się racjonalizacja kosztów produkcji mleka, która zapobiegnie spadkowi dochodowości na skutek zmniejszenia poziomu cen. $Z$ drugiej strony możliwe staje się zwiększenie produkcji mleka poprzez powiększenie posiadanego stada, co wymagać jednak będzie dużych nakładów inwestycyjnych. 


\section{Literatura}

Artyszak A. [2009], Następstwa trzech lat obowiazywania reformy rynku cukru w UE, Zeszyty Naukowe SGGW w Warszawie, Problemy rolnictwa światowego, t. 8, Wydawnictwo SGGW, Warszawa.

Baer-Nawrocka A., Kiryluk-Dryjska E. [2010], Wpływ likwidacji kwot mlecznych na sytuację produkcyjną i ekonomiczną producentów mleka w Unii Europejskiej (wyniki symulacji modelowych), „Wieś i Rolnictwo”, nr 3(148).

Biuletyn informacyjny ARR [2011], nr 2.

Biuletyn informacyjny ARR [2012], nr 2.

Bouamra-Mechemache Z., Jongeneel R., Requillart V. [2008], Removing EU Milk Quotas, Soft Landing versus Hard Landing, http://www.oecd.org/agriculture/44734064.pdf (9.11.2012).

„Gazeta Cukrownicza” [2010], nr 3.

Informacja ARR o sytuacji na rynku rolno-żywnościowym w marcu 2012 r. wraz z elementami tendencji rozwojowej [2012], Biura Analiz i Prognoz ARR, nr 4.

Mucha M. [2010], Stan i perspektywy branży cukrowniczej w Polsce. Podsumowanie reformy regulacji rynku cukru w UE w latach 2006/2007-2009/2010, „Gazeta Cukrownicza", nr 3.

Olkowska O. [2012], Raport Rynek mleka, styczeń.

Requillart V. [2008], Economic Analysis of the Effects of the Expiry of the EU Milk Quota System, IDEI Toulouse, http://idei.fr/doc/by/requillart/report5_summary.pdf (9.11.2012).

Rozporządzenie Rady EWG nr 1009/67 z 18 grudnia 1967 r. w sprawie wspólnej organizacji rynku cukru, Dz.U. 308 z 18 grudnia 1967.

Rozporządzenie Rady (WE) nr 72/2009 z 19 stycznia 2009 r. w sprawie zmian we wspólnej polityce rolnej poprzez zmianę rozporządzeń (WE) nr 247/2006, (WE) nr 320/2006, (WE) nr 1405/2006, (WE) nr 1234/2007, (WE) nr 3/2008 oraz (WE) nr 479/2008 i uchylające rozporządzenia (EWG) nr 1883/78, (EWG) nr 1254/89, (EWG) nr 2247/89, (EWG) nr 2055/93, (WE) nr 1868/94, (WE) nr 2596/97, (WE) nr 1182/2005 i (WE) nr 315/2007, Dz.Urz. UE L 30/1.

Rynek cukru. Stan i perspektywy [2011], IERiGŻ i ARR, Analizy rynkowe, czerwiec.

Rynek mleka, stan i perspektywy [2011], IERiGŻ, nr 41, wrzesień.

Rynek cukru - stan i perspektywy [2012], IERiGŻ Państwowy Instytut Badawczy, ARR, nr 39, czerwiec.

Rynek mleka, stan i perspektywy. Analizy rynkowe [2011], IERiGŻ i ARR, kwiecień.

Seremak-Bulge J. [2011], Rynek mleka na progu 2011 roku, „Przemysł Spożywczy”, nr 3.

Stankiewicz D. [2006], Reforma sektora cukrowniczego w UE, Biuro Studiów i Ekspertyz Kancelarii Sejmu, Informacja nr 1243.

Szajner P. [2009], Ocena wpływu reformy systemu regulacji rynku cukru w Unii Europejskiej na polski przemyst cukrowniczy, Zeszyty Naukowe SGGW w Warszawie, Problemy rolnictwa światowego, t. 8, Wydawnictwo SGGW, Warszawa.

Szajner P. [2011a], Rynek cukru i artykułów cukierniczych w Polsce, „Przemysł Spożywczy", nr 6.

Szajner P. [2011b], Aktualne problemy polskiego mleczarstwa, „Przemysł Spożywczy”, nr 10. 
Śmigielska D. [2013], „Rynek Mleka”, nr 7, Polska Federacja Hodowców Bydła i Producentów Mleka.

Świtłyk M., Wilczyński A. [2012], Sytuacja ekonomiczna gospodarstw mlecznych po likwidacji systemu kwotowania produkcji mleka, „Wieś i Rolnictwo”, $\mathrm{nr}$ 1(154).

Zmiany na rynku mleka - sezon 2010/2011 [2011], Biuletyn Agencji Rynku Rolnego, nr 2.

\section{Perspectives of Development in the Sugar and Milk Production Industries in Poland in the Light of Changes in CAP until 2020}

The article discusses problems in the development of the milk and sugar sectors in Poland from the point of view of changes in the Common Agricultural Policy until 2020. The article summarises the reforms that have been made on both markets, and examines trends expected in the development of these sectors in the new programming period.

Keywords: sugar market reform, milk market reform, production quotas, common agricultural policy. 